\title{
Instrumentation of the Creative Economy Under the Theory U Concepts
}

\author{
Flávio de São Pedro Filho ${ }^{1}$, Maria José Aguilar Madeira ${ }^{2}$, Manuel Antonio Valdés Borrero ${ }^{3}$, Gelson Barros Cardoso ${ }^{4}$ \\ \& Sony Helthon Alves dos Santos ${ }^{5}$ \\ 1 Post-Doctor in Management and Economy, University of Beira Interior, Covilhã, Portugal; Doctorate in \\ Administration from USP, Brazil Coordinator of the Research Group on Management of Innovation and Technology \\ (GEITEC / UNIR / CNPq), Brazil \\ ${ }^{2}$ Doctor in Management and Economics, University of Beira Interior \& NECE-UBI Research Centre, Covilhã, \\ Portugal \\ ${ }^{3}$ Economist and Doctor in Electrical Systems Planning, Associate Researcher of GEITEC / UNIR / CNPq, Brazil \\ ${ }^{4}$ Master in Professional Public Administration, Federal University of Rondônia, GEITEC Member / UNIR, Brazil \\ ${ }^{5}$ Academic in the course of Economical Sciences, Federal University of Rondônia; PIBITI Scholarship holder \\ /UNIR, Brazil
}

Correspondence: Flávio de São Pedro Filho, Post-Doctor in Management and Economy, University of Beira Interior, Covilhã, Portugal; Doctorate in Administration from USP, Brazil Coordinator of the Research Group on Management of Innovation and Technology (GEITEC / UNIR / CNPq), Brazil. E-mail: desaopedrofilho@unir.br

Received: July 16, 2021

doi:10.5430/ijba.v13n1p48
Accepted: August 23, 2021

Online Published: January 5, 2022

URL: https://doi.org/10.5430/ijba.v13n1p48

\begin{abstract}
The West Amazon peoples show a low economic and social development pattern, even when there are plenty of natural resources. It looks like there is a huge gap between these resources, the investments, the knowledge, and the public policies able to create a better life quality for the Amazonians. This work looks forward to promoting the development of the Amazon according to ways shown by the creative economy and the U Theory, special attention will be given to the Amazonian situation and the path to its cognitive development and subsequent economic development. The work is in the academia and communities that search for a viable alternative to creative and sustainable development. From this standpoint, the proposed general objective is to study the instrumentation of the creative economy with input from the U theory. As specific objectives: to perform a critical analysis of the raised concepts (1); to point towards the circularity elements of the creative economy in the community (2); and refer to the acknowledged instrumentation in this study in support to the creative economy, having as baseline the U Theory (3). Hence, the problem proposed is: how the concepts brought up by the creative economy with the support of the U Theory can contribute to the West Amazon's economic, social and sustainable development promotion. It is meant as qualitative research with a content analysis method, in which the data was gathered through bibliographic search and interviews. In the results, it is proposed a competence and ability management space to the leaderships, beginning at the Amazonian home. It is due to capacitating and training these producers under innovation, entrepreneurship, and sustainability concepts. It is requested the attendance to rules and techniques be respected by the producer of products elaborated with the available raw material.
\end{abstract}

Keywords: administration, Amazon, creative economy, management, $U$ theory

\section{Introduction}

The Brazilian West Amazon, social-geographical space outlined by poverty extremes in a rich and promising environment. What takes place, in this scenario, is that attributes that could come from the Amazon Forest, by the residents' initiative, don't wake on the stakeholders a perception to make progress happen. However, the guided study could offer an ideal way to these individuals' success, having the creative economy as the logical argument and the U Theory to advance to the social, environmental, economic, and institutional effects.

This study focuses on the Creative Economic instrumentation under the U Theory's eyes and the many concepts around this circularity. This study is justified by the lack of dissemination in this subject area, longing for qualitative research that shouts out the concepts related to this approach, fulfilling the knowledge and critic in academia. 
According to Silva (2018), this market's occurrence is recent, which causes an expression of chains of theories on the way to consensus attainment. On this matter, the reason that shows itself as the most interesting to the elaboration of this research is to answer the following question: How the concepts raised about the creative economy with the support of the application of the U Theory can promote sustainable development in the Brazilian West Amazon? The general objective proposed is to study the instrumentation of the creative economy with backing from the U Theory. And for the results bring as specifics objectives to perform a critical analysis of the raised concepts; to point towards the circularity elements of the creative economy in the community innovation; and to refer to the acknowledged instrumentation in this study in support to the creative economy, having as baseline the U Theory. The used method will be the content analysis method to understand the scientific and bibliographical production about the topic.

This document is constituted of topics and subtopics grouped which, after this introduction, brings a theoretical-conceptual revision, next comes the methodology, the results, furthermore the logic previously established by objectives, the conclusion and, therefore, the references used as support to the study.

\section{Theoretical-Conceptual Revision}

Over time, the notion of development has been transformed by the search for a more efficient concept. However, the generalized way of implementing this concept has given few results. Thus, comprehensive economic and social policies sought to leverage economic growth, as it was only with GDP growth that the development of society can to be achieved, as was thought in the past in accordance to Siedenberg (2001).

The development seen in this aggregated way, omitted the specificities of the localities and individuals who occupy them. In the evolution of the development concept, more local-oriented development proposals emerged, in order to engage communities, their culture and everyday knowledge as comments Chiasson (2003).

According to Buarque (2002), "local development depends on the capacity of actors and local society to structure and mobilize themselves, based on their potential and cultural matrix, to define and explore their priorities and specificities". There is nothing better than promoting development based on the creativity of the agents involved locally. According to DUISENBERG (2008), the creative economy can overcome the challenge of social inclusion.

Lelis and Brasil (2018) address the historical context of the creative economy, point that the proposition to the resolution of an economic problem can be in using technology and culture. These authors' perceptions go back to the Australian reality of their studies about sustainable products and services development. They indicate the inversion of the effects of globalization and consider the local opportunities for development, which lead the movement denominated Creative Nations. The raised bibliography indicates, still, that British scholars also have drawn upon culture and creativity to revitalize degraded industrial areas, having applied such concepts on the fight against poverty, as a way to promote social development; it arises here the first concepts of creative industry as an approachable to distinguish companies that use creativity on the development of new products and services.

According to Oliveira and Starlin (2012), the notion of creative industry is aggregated to creative economy, integrating other subsidiary services with those related to publicity and advertisement, architecture, fine arts, antiquity, performing arts, scenic, craftsmanship, design, fashion design, audio-visual, music, publishing market, literature, software, games, television, and radio. The creative economy presents itself as pivotal on the creative process of diverse sectors and services.

\subsection{Concepts About Creative Economy}

The concept of creative economy is still receiving different treatment in the international scope because international bodies envision in this model a form of protection to fundamental rights, recovery of underdeveloped areas, and improvements in income distribution. To Lelis and Brasil (2018) the creativity is booming. The word got an eye on creative economy and has already noticed its relevance because of its competitiveness and invests in the creative development of individuals that are responsible for the company's growth. In this new economy where the customer is the new guiding, the entrepreneur class changes the old ways of gaining new ways based on innovation and technology. Still, in accordance to the authors, the creative economy stands out because of the changes provoked inside the production chains due to the potential that technology, culture, and innovation, other than knowledge and information, generates on urban restructuring, the forming of life habits, the creation of jobs and income, the promotion of new social groups on the market and the cost reduction of products and services; but the main differential is the sustainable development, having as source the human being. Therefore, when creativity and knowledge are valued and used as a primary source of activities, the creative economy places other dimensions as key points, leaving secondary the financial and products dimension. Search at De Marchi (2014) points that Creative Economy is one of the pillars of development in many countries. Creativity is inherent to the human person and, by 
so, an immaterial resource that can promote the development independently of the stage that your economies are placed.

Madeira (2014) explained that it's in the creative economy that the digital revolution's characteristics are inserted as capitalization elements of knowledge and creativity. For such cognitive action to occur, the search to fit the economic imperatives and patrimony will be fundamental. On the other hand, to Lelis and Brasil (2018), creative economy is the alignment of cultural diversity, human knowledge, and the technology essential to the making of tradeable products and services; it can be included cultural content protected through intellectual property rules, on a certain alignment that characterizes the economic activity organization. In the creation of something new, many processes are required. This creative process is firstly given in a person's mind, and this creative thinking can only occur if there's interest in obtaining something new; the inspiration is responsible for the production of a good idea, for all of this to happen, time is necessary, this time, being it brief or long, is what will mature the process.

Madeira (2014) stresses that the creative economy has begun having attention from countries as Australia, China, South Africa, and India, where is applied as a strategy vector. In Australia, the author registers the success of the using of creative economy concepts in areas of interactive media, electronic games, and general entertainment; there, the public power invested these conceptual elements on gastronomy, fashion, design, and architecture sectors, as well as on the artistic promotion amongst its aboriginals. In China, a meaningful development occurred in applying the concepts of creative economy on information and digital entertainment areas, in return exerting dominion over the market, becoming the main importer of products made under such concepts. Meanwhile, in South Africa, audio-visual has been the main highlighted focus of the creative economy; likewise, it was invested in craftsmanship and publishing too. And in India, it has been intense investment in software, mainly in film production, weaving, design, and fashion.

In this study, the classic concepts of creative economy have support on Barcellos et al. (2016), De Marchi (2014), Madeira (2014), Lelis e Brasil (2018) pointed out their concepts about the topic. To Barcellos et al. (2016), the creative economy, previously known as creative industry, emerges from integrating creativity, culture, technology, innovation, and economy. Following this reasoning, De Marchi (2014) points to creativity as the main way to developing countries. The author agrees that creativity promotes its development independently of how the economy is in the country because it is inherent to the human being and a nation's immaterial resource. As exerting creativity can't be stopped unless there are public policies on this matter, and for being an infinite resource, it promotes the nation's development when well used. On the other hand, to Madeira (2014), the creative economy is intrinsically related to the digital revolution that raises its use for knowledge and creativity.

Lelis and Brasil (2018) update the concept that intellectual property may be an organizational factor in economic activity in certain areas. This concept is the most similar to today's reality because the musical area is one of the most growing areas in this economic segment; indeed, also, it's protected by laws of intellectual rights, in addition to others. In all this process, all the concepts follow the timeline where there are important characteristics placed in each one of them, contributing to a better comprehension of the topic.

\subsection{Concept About the Circular Economy Model}

According to Ribeiro (2018) circular economy proposes a sustainable development with the return of the material to the production cycle through a model that allows the reuse, recovery, recycling, and repair. Comparing both models in the linear economy, the product after consumed is disposed of without intention of sustainability, and, in the circular model, it's searched the restoration of natural resources and the minimization of those, of energy and emissions.

To Abramovay (2015), by benefiting the economy, circularity becomes a relevant contemporary innovation. It promotes a promising direction to growing and economic development because it reduces the country's dependency on primary products. This way suits itself of particular importance the application of this model to sustainable development. The circular economy is a good example of the creative economy as it allows transforming garbage or waste into new products in a creative and inclusive way.

\subsection{Concepts About the Linear Economy Model, Circularity, Transversality}

Thinking of trash disposal and raw material scarcity, the resources are treated as if they would never end, being so, inside a linear model. The linear economy follows the following view: extract - produce - use - dispose, in this, the linear model promotes many external problems; it will cause climatic impacts, energy waste, material disposal, and ecosystems poisoning, amongst others; if we analyze the linear model in the long term, we'll conclude that there's no sustainability, in conformity with Ribeiro (2018). 
According to Dodsworth (2016), the linear model rules the production system on a global scale. The linear model takes the raw material extraction and its use on the product creation, consumed and disposed of, returning to nature without reuse, requiring constant extraction of raw material, where a simple interruption would cause chaos, collapsing the whole model. According to Stahel (2016), the linear economy follows well-defined steps; by the added value, transform the natural resources to raw material and to products which are put on sale; after the sale, the risk and responsibility are passed on to the customer who becomes the owner of the products and, by so, responsible for the trash disposal. On the other hand, the circular economy works the reuse, reducing so the: consumption, waste and also saves energy and generates employment. In Figure 1, it is shown how the linear system and the circular system work, and Table 1 shows the detailing of each step of the model.

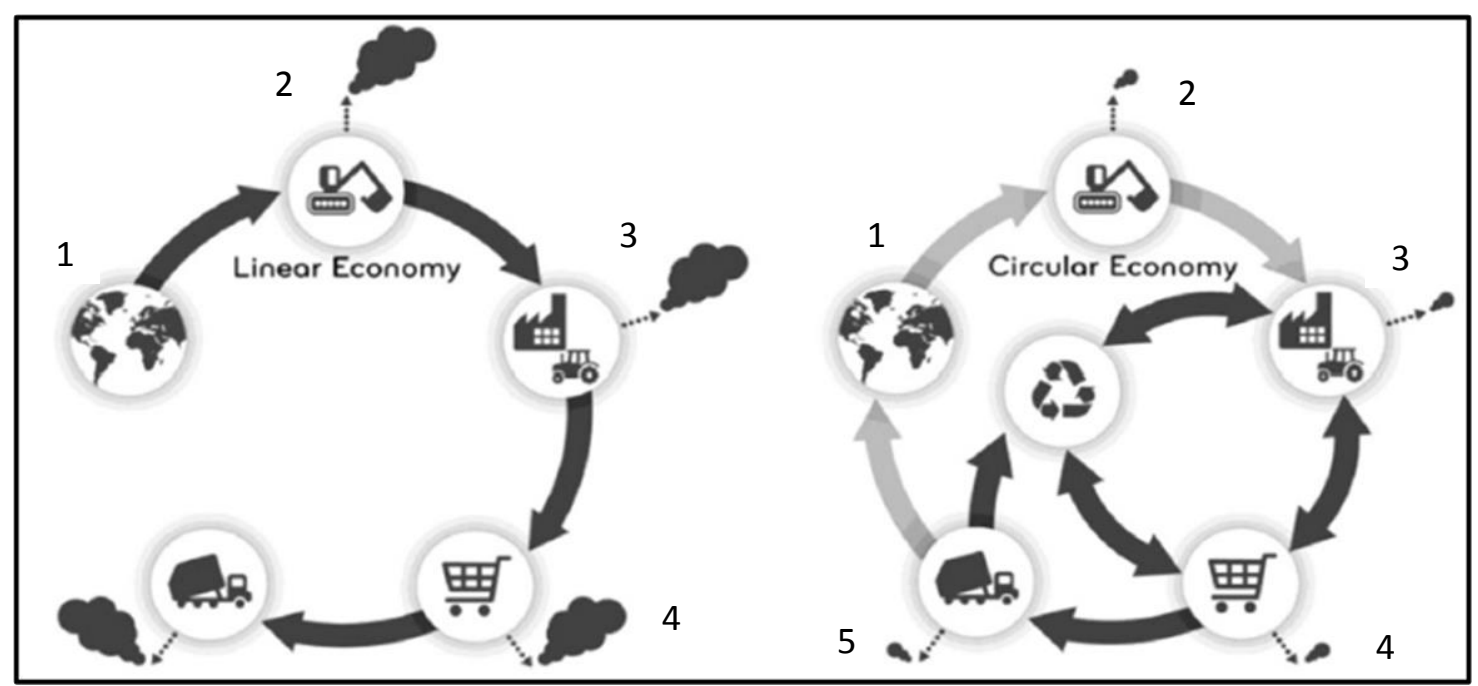

Figure 1. Production cycle in the linear and circular economy models

Source: Sauvé, Bernard and Sloan (2016).

Table 1. Detailing of the production cycle in linear and circular models of the economy

\begin{tabular}{lll}
\hline Steps & Linear Economy & Circular Economy \\
\hline 1 - Start of the Cycle & Source of resources, Nature; & Source of resources, Nature; \\
\hline 2 - Extraction: & $\begin{array}{l}\text { The resources are extracted in a } \\
\text { non-sustainable way. }\end{array}$ & $\begin{array}{l}\text { Resources are sustainably taken from } \\
\text { nature, without degradation, and with the } \\
\text { least impact. }\end{array}$ \\
\hline 3 - Industrialization: & $\begin{array}{l}\text { The resources are industrialised, } \\
\text { made into products for sale; }\end{array}$ & $\begin{array}{l}\text { The resources are extracted, treated, and } \\
\text { made into products with little to no } \\
\text { environmental aggression. }\end{array}$ \\
\hline 4 - Trading: & $\begin{array}{l}\text { The products are put on sale. In } \\
\text { acquiring the products, the customer } \\
\text { is responsible for its disposal. }\end{array}$ & $\begin{array}{l}\text { The products are put on sale. The trash } \\
\text { produced is biodegradable. }\end{array}$ \\
\hline 5 - Disposal: & $\begin{array}{l}\text { When disposed of, the trash goes } \\
\text { back to nature without due } \\
\text { treatment, taking, many times, } \\
\text { decades to decompose, bringing } \\
\text { problems to the environment, and } \\
\text { ending the cycle. }\end{array}$ & $\begin{array}{l}\text { The disposal is made by natural means with } \\
\text { no aggression to the environment because it } \\
\text { restarting the cycle. }\end{array}$ \\
&
\end{tabular}

Source: Made by authors. 
Marcondes et. al (2018) state on the contentious conceptual surging of transversality. As it shows on IPEA 2009 data, considered a new approach to the education process, this concept has its origins in education studies and spread to diverse areas as Sociology, Philosophy, and Psychology.

\subsection{Concepts About Interdisciplinarity, Transdisciplinarity and U Theory}

Readings at Araújo et al. (2015) address the depth of interdisciplinarity in research on management and approach the investigative work strategy to two or more subjects about a problem combining both axes of interconnectivity, and intellectual integration engineers and economists tend to disagree. At the same time, transdisciplinarity concerns methodological pluralism on the knowledge construction in reality with temporary answers about researched objects. It is a hermeneutic exercise in the search for concepts in its contextual limits using a critical exercise that transgresses the formality and the oppression that hinder the search for creativity that envelop research. It is surmised from the reading of Serralvo and Cardoso (2009).

The $U$ Theory is an organizational learning method that aims to implement change focused on management productivity. The U Theory follows seven established steps, and those are: to suspend, to redirect, to let go, to be present, to let come, to decree the law, and to incorporate. These steps follow a defined route which has a "U" format, that is where the name comes from; however, as it is not possible to know everything through the existence of blind spots, the U Theory helps us, from self-knowledge, to better see the whole; improving the ability to choose what to see, is possible to choose the own world and build the own self, according to Scharmer (2010). In all this process, it's evident the need to combine these strategies with a modern method to face the challenges that emerge to the creative economy.

However, historically, the Amazon population has been characterized by a low educational and technological level, as well as the unavailability of technical knowledge and financial resources to undertake business in the traditional sectors of the economy. Therefore, the Theory U provides the necessary impetus for Amazonian communities and individuals, based on little explored natural resources and self-knowledge, to undertake creative activities in their own favor.

\section{Methodology}

This research is of qualitative and descriptive nature. According to Moreira and Caleffe (2008), qualitative research refers to a group of research traditions that uses different theoretical-methodological standpoints but has in common the typical characteristics of qualitative research. The ethnography, the biography, the case studies of phenomenological nature, and others are examples of these traditions. In conformity to Marconi and Lakatos (2017), the qualitative research has as objective to comprehend the studied object singularly, as if in a task like this, which will adopt the Content Analysis Method; it is considered as an analysis technique of qualitative data, as treated by Lal Das and Bhaskaran (2008), from the approach about the scientific study in communication content; this means that a study references the meanings, intentions, and contexts deemed in the message, as this task proposes it.

\subsection{About the Method}

To Gonçalves (2016), the Content Analysis Method is a technique used by human and social sciences to investigate symbolic manifestation thorough research techniques. The procedures for this method are given in Schiavin and Mortari (2018) when the authors comment that it aims to employ quantitative and qualitative operations in the text or the communications transcriptions, operating directly on those as mentioned above, that is, it is a systematic and objective description of the content.

\subsection{About the Cleavage and Categorization Procedures}

This work brings as procedures the bibliographical search, having selected books, articles in magazines, and specialized journals, written by consecrated authors, which cover the approached subject. Another procedure is the analytical selection of bibliography and referred works about the theme, with indexed sources, primary or secondary. The research task acknowledges the cleavage practice and a valid corpus characterization to the desired covering about the subject.

Sylwia Mikołajczak (2003), addressing the cleavage process, agrees that it has as objective to signal the main element of the researched object, permitting to place in evidence the most relevant obtained information, as means to improve the comprehension of the facts that will guide the narrative. Likewise, it is possible to comprehend that cleavage, while pointing to determined elements, transmits direct valid information to the recipient, which causes great improvements in the cognitive element, inducing the accuracy of what would presumably be wrong or false in new information. 
According to Lima (2010), the process of categorization consists of grouping data according to its resemblance. This grouping addressed in Pedro Filho et al. (2017) forms analysis categories. Still on Lima (2010), the worrying with the categorizing practice revives the Aristotle period, because, with the changes in cognitive science studies, the categorization has passed by changes, and this provoked a change in the categorization procedures, it passed from an individual cognitive process to a social process of reality building based on culture.

The categorization can only be produced from something real because information only comes from the real world; it will produce new knowledge as the data grouping and the analysis of its similarities and differences.

\subsection{About the Measurement Procedures in Cronbach Alpha, Likert Scale and Treatment by the Excel Software}

The Cronbach Alpha Coefficient was used to analyse the Query Form's validity and reliability on the virtual Platform for answering performance. This allowed us to agree that this research instrument meets the intended measurement requirements in the face of respondents' perceptions, which can be seen in the organizational environment variables. Hora, Monteiro and Arica (2010) advised these are arrangements, having allowed confirming the rule here adopted positively. According to Cunha, Neto and Stackfleth (2016), Corrar, Paulo and Filho (2017) and Gottems et al. (2018), the assumed value by the Alpha is between 0 and 1, and the closer to 1, the bigger is the reliability of the construct dimensions. But, there's no defined minimum value for the Cronbach Alpha coefficient to be accepted as good. But the writing shows the 0,70 value as an acceptable minimum. The result obtained at the test is 0,821 , which confirms the high validity degree and the form reliability, being so, considered suitable to the research, following the recommendation from quoted authors, making the results performance far more reliable.

The Likert Scale is a stand scale largely used in preference, tastes, and perceptions matters. By its simplicity and easy understanding, it is fairly used in studies that use surveys answer. It is understood by Curado et al. (2014), the Likert scale allows us to use data from people through answers via the form. For this, the method backs itself on scale building, making possible the opinion treatment and diverse points of view.

\section{Study Results About the Instrumentation of the Creative Economy Under the U Theory}

The researched stage is the West Brazilian Amazon one, a social-geographic space outlined by poverty extremes during a promising and wealthy environment. What occurs is that, in this scenario, the attributes which could come from the Amazon Forest, by the resident initiative, don't awake in the stakeholder a perception to make progress happen. However, the oriented study could offer the ideal way to these individuals' success, having the creative economy as a logical argument and the U Theory as a tool for the advances towards the social, environmental, economic, and institutional effects. In this case, the critique of this complexity is locked from the respondents' perception to emerge an answer to the task objectives.

\subsection{Raised Concepts Critical Analysis in the Face of the Amazonian Perception}

To the extent of elements to be critiqued, the methodological requirements indicated in this same study topic have been met. A respondents' platform has been made available, and the respondents were able to state themselves what allows bringing the perception to the expected content analysis, as the following Table 2 suggests.

Table 2. Indicators summary about the consulted stakeholders' perception

\begin{tabular}{|c|c|c|c|c|c|c|}
\hline Affirmatives & TD & PD & $\mathbf{I}$ & PA & TA & $\mathbf{T}$ \\
\hline Technology and culture can solve economic problems. & $0 \%$ & $4 \%$ & $9 \%$ & $49 \%$ & $38 \%$ & $100 \%$ \\
\hline Creativity promotes development. & $4 \%$ & $2 \%$ & $2 \%$ & $47 \%$ & $45 \%$ & $100 \%$ \\
\hline $\begin{array}{l}\text { In the creative economy the customer determines the consuming } \\
\text { pattern }\end{array}$ & $2 \%$ & $11 \%$ & $13 \%$ & $51 \%$ & $23 \%$ & $100 \%$ \\
\hline Poverty can be fought with creative economy. & $2 \%$ & $6 \%$ & $4 \%$ & $49 \%$ & $38 \%$ & $100 \%$ \\
\hline New products and services surge with creative economy. & $0 \%$ & $6 \%$ & $0 \%$ & $28 \%$ & $66 \%$ & $100 \%$ \\
\hline Creative Economy is competitive. & $0 \%$ & $4 \%$ & $13 \%$ & $47 \%$ & $36 \%$ & $100 \%$ \\
\hline Creative Economy invests in creative development. & $2 \%$ & $0 \%$ & $2 \%$ & $49 \%$ & $47 \%$ & $100 \%$ \\
\hline The Creative Economy differential its sustainable development. & $2 \%$ & $4 \%$ & $13 \%$ & $55 \%$ & $26 \%$ & $100 \%$ \\
\hline
\end{tabular}




\begin{tabular}{lllllll}
\hline Circular economy looks for the recovery of natural resources. & $0 \%$ & $2 \%$ & $13 \%$ & $62 \%$ & $23 \%$ & $100 \%$ \\
\hline Linear economy promotes climatic impacts. & $2 \%$ & $11 \%$ & $26 \%$ & $38 \%$ & $23 \%$ & $100 \%$ \\
\hline The linear system rules the world production system. & $4 \%$ & $11 \%$ & $32 \%$ & $34 \%$ & $19 \%$ & $100 \%$ \\
\hline Possible organizational changes focusing on productivity. & $4 \%$ & $2 \%$ & $15 \%$ & $47 \%$ & $32 \%$ & $100 \%$ \\
\hline Produced self-knowledge helps seeing the whole better. & $0 \%$ & $0 \%$ & $6 \%$ & $32 \%$ & $62 \%$ & $100 \%$ \\
\hline It's possible to choose the own world and build the own self. & $2 \%$ & $17 \%$ & $13 \%$ & $32 \%$ & $36 \%$ & $100 \%$ \\
\hline
\end{tabular}

Source: Data collected by authors.

In conformity with the above data, $49 \%$ of the consulted Amazonians agree partially that technology and individuals' culture can help resolve their problems, whereas 38\% totally agree with this fact. Therefore, it is clear the $87 \%$ of respondents' agreement, corroborating with the approach brought by Lelis and Brasil (2018), that technology and culture can support the resolution of the economic problem of society. These scholars focused on the Australian reality to interpret the product development from the standpoint of environmental services offered by nature, as it's the Amazon Forest case which has a series of attributes to be explored and reverted in consuming products. A recently published note in the region tells us about a chocolate brand extracted from the forest cocoa, a product developed by tribal individuals, with the appropriate technology created, having as raw material this Amazon fruit. As the same token as this indicative, a series of other products could be adequately brought up, practiced, and offered through Lelis and Brasil (2018) concepts, making it possible to revert the extreme poverty and socioeconomic degradation of the Forest retained peoples.

Creativity is another logical argument that contributed to the individuals' development improvement with a desire to change their lifestyle. And the creative economy will allow such concepts to generate structural means, as creators, source indicators, and products to be transformed, notations about the material, raw material, and manufacturing changing tools.

The respondents' perception indicates a bias towards technology and creativity; on the other hand, it indicates social actors limitations if we consider their condition as isolated individuals, reliant on clearing in their understanding, which brings the need for qualification, training, and ability development workshops on the specific knowledge axis, to the extent that Lelis and Brasil (2018), make emerge the way to the creative industry that sustains the creative economy itself. As the stakeholders answered with proficiency to the affirmatives in this matter, with $92 \%$ of agreement, it is fitted to measure their standards on the investigative scenario. In the Amazon it is identified a critical sense predominance to spontaneous innovation from natives; they invented wild cocoa chocolate, prepared on the village, with wooden oven, in their ancestors' molding, with a signature flavor and satisfactory acceptance on the customer sale, as it is pointed out by Figure 2 below.
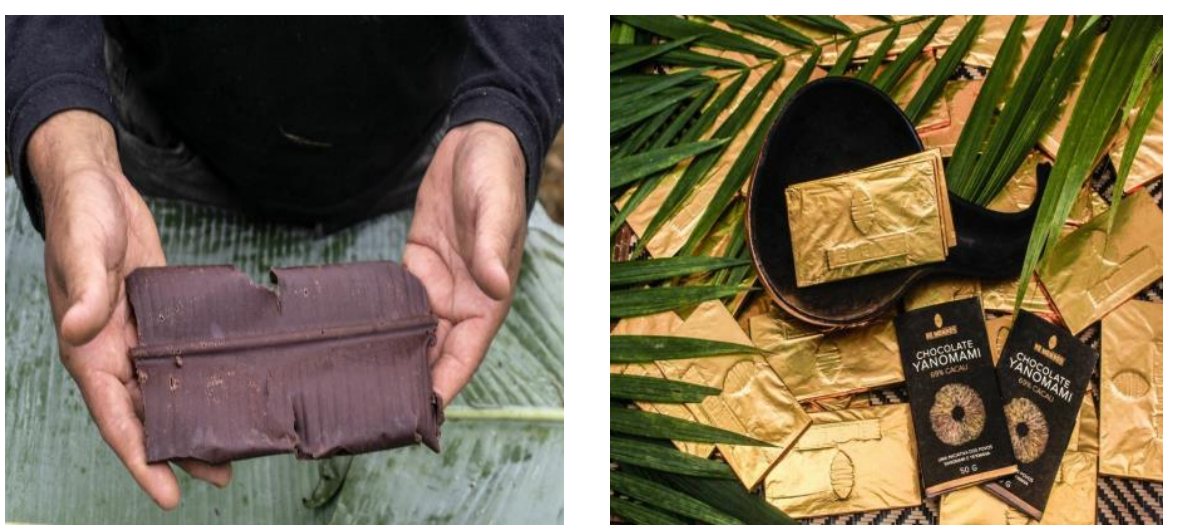

Figure 2. Chocolate produced on banana leaf by Yanomami and Ye'kuana natives

Source: Internet, public domain. 
The study shows that the chocolate production pointed out above was an action taken by traditional peoples to preserve the Amazon Forest, in an effective reaction against prospectors and illegal deforesting on their outlined territory; it would be a decision from the tribes on taking advantage of available natural resources, in a preservationist way, absolutely opposed to the destruction which advanced with unregulated gold extraction from the region. Here is confirmed the theoretical assumption of Lelis and Brasil (2018), which considers creative economy as a tool that promotes sustainability.

Analysis from inquired data, resulting from the consulted respondents in this research, allows stating an unfavorable economic condition that can be reverted with the creative economy. An 87\% percentage of the respondents agree with Lelis and Brasil (2018) in this understanding. Moreover, as Pedigo (2015) stated, it is by the creative economy, not by social projects, that we'll eliminate poverty. Then, the agents can appropriate from initiatives made to generate products and services, overpassing their economic decline while providing income and progress. Furthermore, $94 \%$ of the respondents agree that new products arise from creativity. Regarding the competitiveness that can emerge from creativity, 83\% agree that with such possibility, in agreement with Muzzio and Barbosa (2018). Figure 3 is the respondents' perception performance on the poverty, surging of new products, and competitiveness issues in the creative economy scenario.

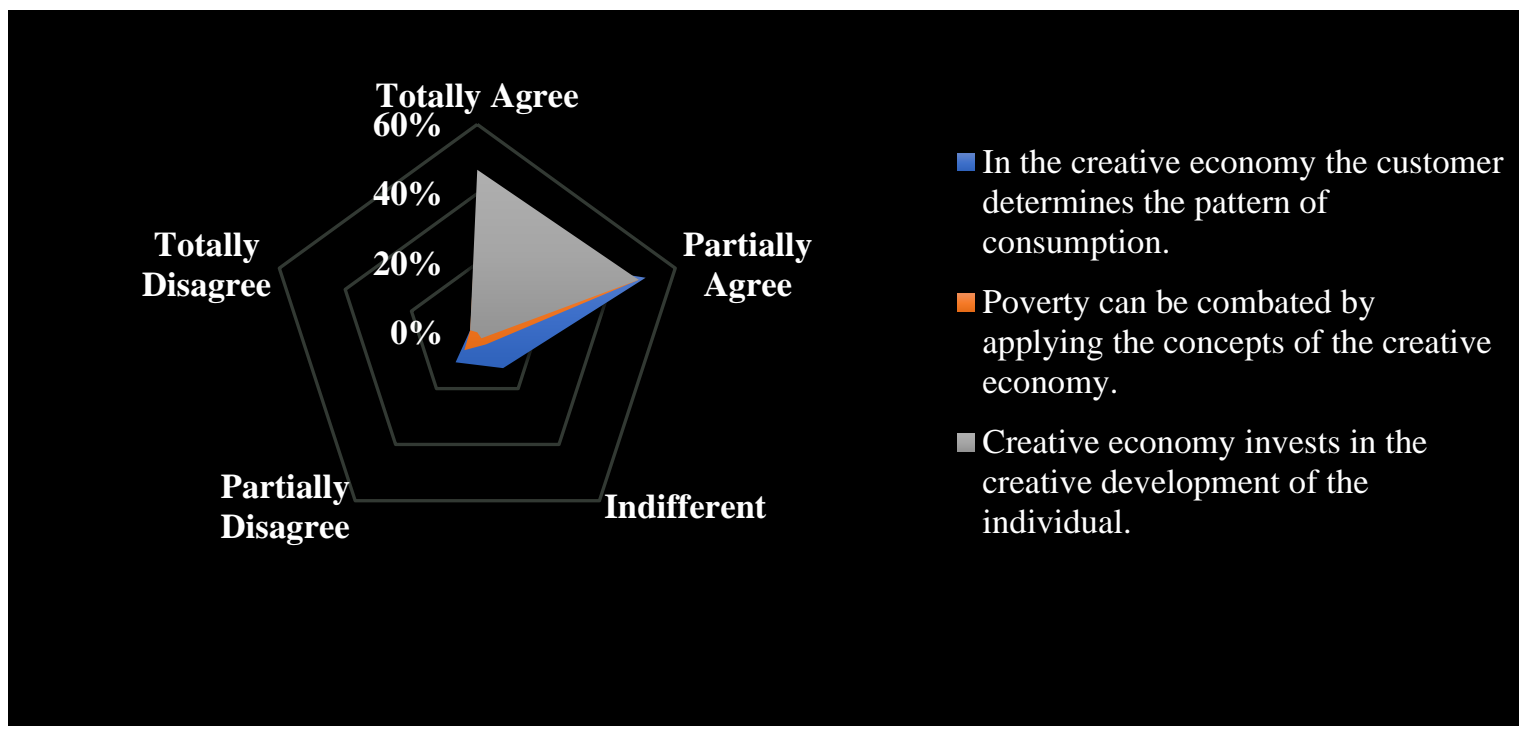

Figure 3. Respondents' perception towards poverty, new products, and competitiveness under the creative economy Source: Data collected from respondents.

The critique about Figure 3 above points out that $96 \%$ of the respondents agree that creativity is valued in the economic scenario. Hence, such understanding converges with statements of Lelis and Brasil (2018) in agreeing that knowledge and creativity can be valued as primary sources in creative economy scenarios; those are central and not secondary dimensions, being able to report to financial and production dimensions, what modifies the life conditions towards the systemic progress substantially.

The study brings elements that allow the comprehension of sustainability and the interpretation of a consumption profile change. Remaining so that, as a fact, the consumers tend to choose sustainable products, like the ones who degrade the least in the manufacturing process. These indicators tend to redirect the management organization to meet the expectations of a select public compromised with a socio-environmental balance. Here is where creative companies are born, operating strategies in favor of worldwide sustainability. Moreover, try to obtain certifications that grant credibility by adopting such adequate procedures.

In this way, the eco-innovation treated in Cardoso et al. (2020) has adherence in the creative economy, making it possible to the business clients to determine the consumption pattern. These are arguments that correlate with the view of $74 \%$ of the respondents in this research. Still, by the same view it is possible to see that $86 \%$ of the respondents of this research agree with the creative economy differential through sustainable development. It clears the mind about the need for attention to sustainable products and services consumers from the manufacturing line. 
The study shows, in addition, that $79 \%$ of the respondents agree about the possibility of implementing changes focusing on the productivity of organizations. Figure 4 below points to the perceived performance by consulted social actors in the scope of this explanation.

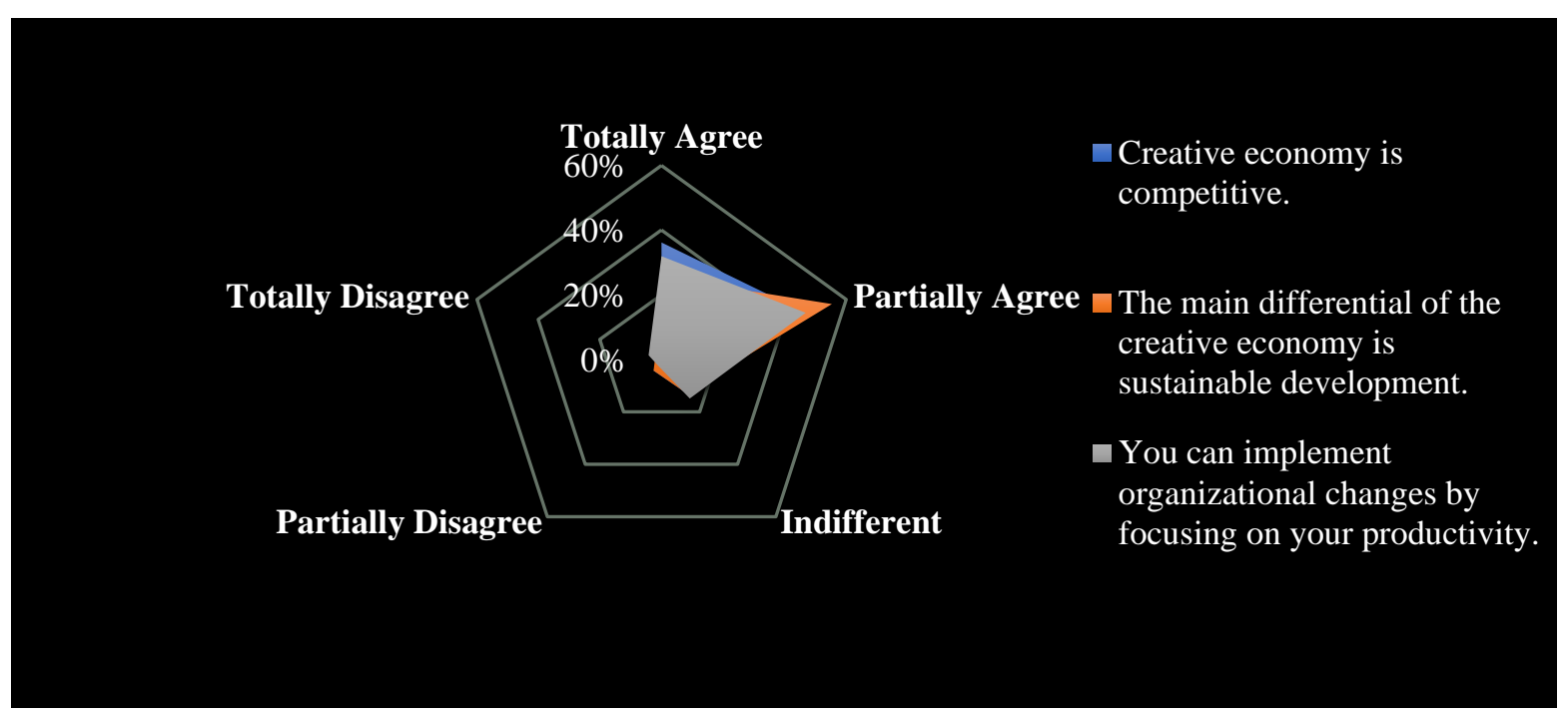

Figure 4. Respondents' perception towards competitiveness, sustainable development, creative economy, and change Source: Data collected from respondents.

\subsection{Arguments About the Creative Economy Circular Elements in Community Innovation}

Recycling on industrial manufacturing is an attraction to these new customers, making that the residues discarded on nature be reduced to zero is to retain costumers worried about the environment. This kind of economy is known as circular and has been a relevant contemporary innovation. The economy is beneficiated by this model, allowing material reuse, recovery, recycling, and reparation. Knowing this, the stakeholders agree that the circular economy searches for the regeneration of the natural resource, adding up an $85 \%$ total. Still, it is not understood because between $85 \%$ and $65 \%$ agree partially with this statement.

Amidst dynamism in a complex and ambiguous world, innovation shows itself as a motor to resolving old and new problems. In Amazon, because of its extension, these problems have been the great agents of development stagnation. In this way, creativity is the tool that will allow regional development advancements in Amazon.

With the disappearance of countless occupations, the surging of others is expected, with this the creative economy instrumentation and, in this case, in the Amazon region, makes itself of utmost importance to make these new occupations emerge, and, by so, creativity employed on the surging of new products and services by the Amazon region residents associated to a methodology of management learning, as the $\mathrm{U}$ Theory is the secret to the region progress.

Information is to the development of these products and services. The more information there is about the region and its inputs, the more the product or service will be accepted by the customer. This information already is a reality passed on from father to son by generation, the big task which this work upholds is to orchestrate this information and turn it into income generation.

In the Amazon context, with the many business options in the cosmetic, bio jewelry, feeding, craftsmanship, natural oils, seasons, and many other areas, that the region presents, it is necessary to take into consideration aspects like sustainability, economy, non-exhaustive extraction, bio-economy, management, as many other aspects.

\subsection{Instrumentation Indication Acknowledged in This Study With Creative Economy Support, Having as Base the U Theory}

The U Theory is a management learning methodology and has as objective the change implementation, focusing on management productivity. It is the most adequate option to the Amazonians' reality; applying this Theory in the creative economy context in the Amazon region into helping the native residents of this region could be a differential to the personal and regional development. This Theory promotes self-knowledge following seven established steps: to 
suspend; to redirect; to let go; to be present; to let come and to choose the own world and build itself according to Scharmer (2010); it has this name because of its shape, as shown, on Figure 5 below, that brings the diagrammed framework in this research; and for a better comprehension of what has been elaborated the Table 3 follows up, in that it sums up the described elements on this picture.

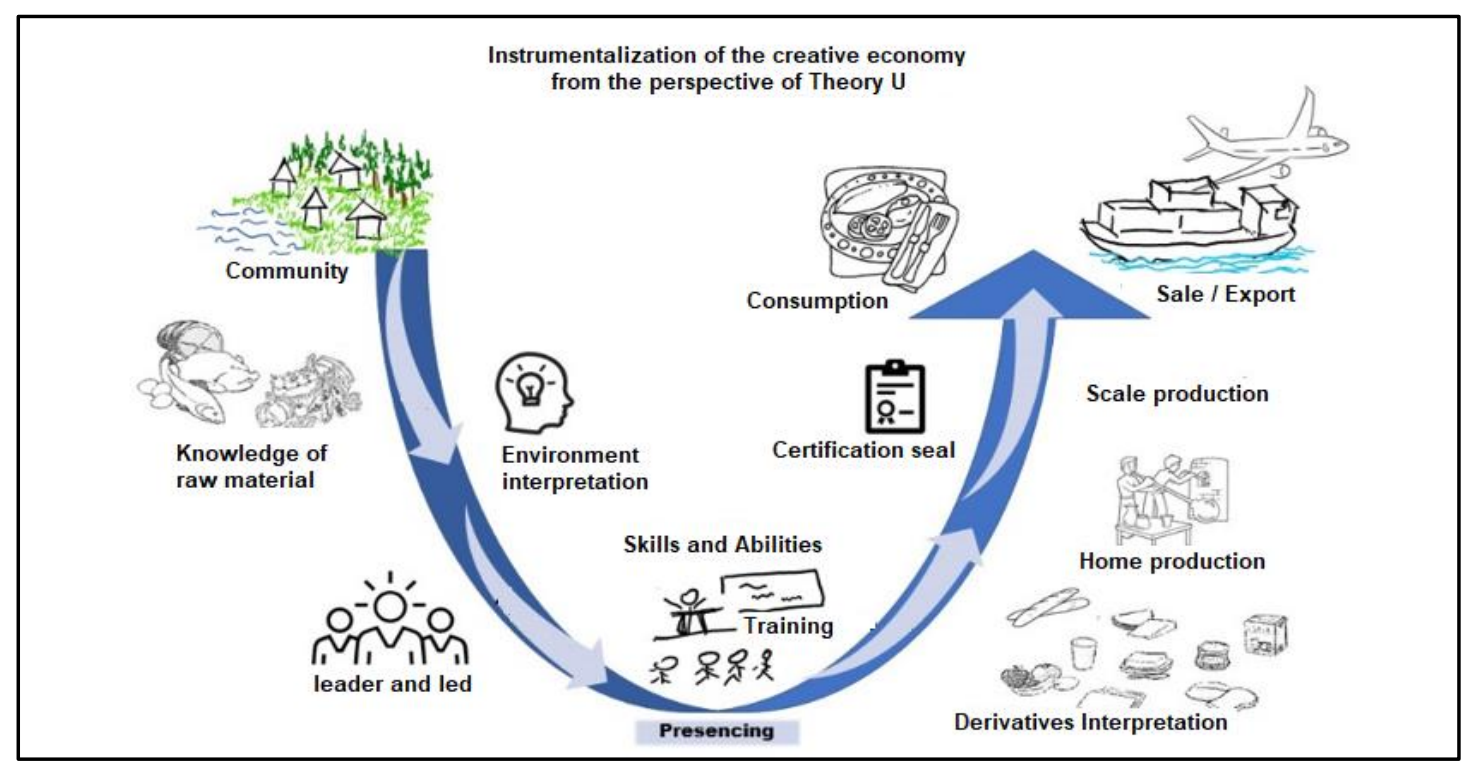

Figure 5. Applicable framework diagram - Creative economy qualification

Source: elaborated by authors.

Table 3. Description of diagrammed elements in the framework

\begin{tabular}{ll}
\hline Steps & Detailing \\
\hline To suspend & $\begin{array}{l}\text { The beginning of the U cycle; in this first step, it is important to know the reality of } \\
\text { the community, its desires, and its needs, and local potential where the agents will } \\
\text { develop creativity to resource generation. }\end{array}$ \\
\hline To redirect & $\begin{array}{l}\text { Here the knowledge acquired through parental transference between individuals is } \\
\text { analyzed; its surrounding interpretations are also important for biases to be put } \\
\text { aside. With this, the knowledge about the raw material can generate resources for the } \\
\text { forest natives. }\end{array}$ \\
\hline To let go & $\begin{array}{l}\text { Opening to a new perception. The old methods are abandoned, and new procedures } \\
\text { and techniques are adopted; a competence and ability rereading about the leaders } \\
\text { and the led is made. }\end{array}$ \\
\hline To be present & $\begin{array}{l}\text { Where the change happens; this is the U Theory turning point. Here through } \\
\text { self-knowledge and training, it is made an interpretation of the derivatives that will } \\
\text { generate resources. A new point of view is recognized. }\end{array}$ \\
\hline To let come & $\begin{array}{l}\text { Once aware of the ecosystem in which they are inserted, the U cycle rise begins with } \\
\text { the development of practical solutions that will become projects or prototypes. }\end{array}$ \\
\hline To decree the law & $\begin{array}{l}\text { The projects and prototypes are idealized and analyzed. Homemade manufacturing } \\
\text { is developed with inputs taken from the forest; now, with new knowledge, } \\
\text { technique, and perspective, the products are placed under tests. }\end{array}$ \\
\hline To incorporate & $\begin{array}{l}\text { After the tests, the production is made on a large scale and under international } \\
\text { parameters focusing on certifications, generating value, and a standard seeking } \\
\text { imports. }\end{array}$ \\
\hline
\end{tabular}

Source: elaborated by authors. 
In this way, $94 \%$ of the researched agreed that the self-knowledge produced helps to see better the whole and $68 \%$ that it is possible to change the world and build the own self, as proposed by Scharmer (2010). The linear model is the most used in global production, the linear perspective defines this model: to extract - to produce - to use - to dispose. This kind of model brings tragic consequences to the environment but doesn't make the residues reused. Under the stakeholders' eye, this model promotes the climatic impacts, but only $61 \%$ agree with the statement, and only $53 \%$ agree that this model dominates world production. The indifferent levels related to the proposition showed up high compared to the other statements being $26 \%$ and $32 \%$, respectively. This shows that knowledge about the linear system is little spread reflecting the researched population knowledge.

Seifert Jr. and Machado-da-Silva (2007) evoke assumptions to industrialization well-accepted by the international community in respecting essential points to competition. International organizations have requested that the means of production adopt an internationalization strategy, that they are homogeneous and isomorphic under the ideals of sustainability. Therefore, by asserting this idea, it is possible to obtain an international acceptance of the products and services extracted from Amazon. For that to be possible, a learning methodology as the U Theory, combined with resources originating from the forest, will result in quality certification.

The competition still demands that there is heterogeneity of resources between organizations, leading to an internationalization strategy distinction. What will be mostly found in the Amazon is diversity. This diversity can be applied from the products making with the same input, between different communities, and generating different products, with the particularity of each community. It is necessary to fortify the capillarity on the industry representation body, mainly when the international community takes a critical look over the industrial fabric, especially to what could be installed in the Amazon. In this way, it is proposed to build a place of expertise and abilities to the leadership's desiring of success, starting there at the Amazonian home. It is due to train these producers under the concepts of innovation, entrepreneurship, and sustainability. It is requested the attendance to rules and techniques be respected by the producer of products elaborated with the available raw material.

\section{Conclusion}

The Amazon region, with all its biome, provides countless possibilities for income generation. It is inadmissible. To see its residents suffering because of poverty and abandon this region to adventure in other places in search of better living conditions is inadmissible. This work showed differently that it is possible, through the behavioral change that the U Theory enables, to elevate the mental qualifications and generate wealth through the forest with the concepts of sustainability, creativity, and innovation.

This work which aims to contribute to the Amazon region development, has shown itself efficient in pointing the creative economy, supported under the U Theory, as the most efficient methodology to reach expected results. With this, taking as a basis the conjuncture of the investigated reality, the $\mathrm{U}$ Theory is an applicable and achievable base in the creative economy, provided that the leaderships desiring of success search and receive capacitation, training, and development on the specific knowledge axis, as the innovation, entrepreneurship and sustainability concepts. The respondents of this research point to the perception of the importance of the creative economy to the communities. Furthermore, it is in the interest of academia and the community to search for viable options for the planet's sustainable development. For all these reasons, it is expected that this work is used as the foundation to sustainable businesses in the Amazon and future research surrounding the subject.

Despite the large number of texts published on creative economy, there is still a gap between theory and practice. Future work should seek to get closer to the potential of Amazonian communities and provide them with the necessary paths and knowledge so that they can explore their natural products sustainably for their own well-being.

\section{References}

Abramovay, R. (2015). A economia circular chega ao Brasil. Valor Econômico, São Paulo. Received May 14, 2019, from http://ricardoabramovay.com/a-economia-circular-chega-ao-brasil/

Araújo, U. P., Sanches, P. F., \& Gomes, A. F. (2015). Desafiando a interdisciplinaridade na Ciência Administrativa: o caso da entropia. Cadernos EBAPE. BR, 13, 664-686. https://doi.org/10.1590/1679-395131772

Bhaskaran, V. (2008). Research methods for social work. New Delhi: Rawat, 173-193.

Buarque, S. C. (2002). Construindo o desenvolvimento local sustentável. Rio de Janeiro: Garamond.

Cardoso, F. A., Faoro, M. F., Brandalise, L. T., \& Bertolini, G. R. F. (2020). Abordagens das práticas de eco inovação: uma revisão sistemática de estudos de casos aplicados em empresas de manufatura. Gestão \& Planejamento-G\&P, 21, 251-266. https://doi.org/10.21714/2178-8030gep.v.21.6589 
Cardoso, O. D. O., \& Serralvo, F. A. (2009). Pluralismo metodológico e transdisciplinaridade na complexidade: uma reflexão para a administração. Revista de Administração Pública, 43, 49-66. Received May 14, 2021, from https://www.scielo.br/j/rap/a/qq5rgkMHQ98JQPg3bJ8CFVR/?format=pdf\&lang=pt

Chiasson, G. (2003). Territories and Actors in Local Development: New Locus of Democracy. Canadian Journal of Political Science, 3(1), 214-5.

Corrar, L. J., Dias Filho, J. M., \& Paulo, E. (2009). Análise multivariada para os cursos de administração. Ciências Contábeis e Economia. Editora Atlas.

Cunha, C. M., de Almeida Neto, O. P., \& Stackfleth, R. S. (2016). Principais métodos de avaliação psicométrica da confiabilidade de instrumentos de medida. Revista de Atenção à Saúde, 14(49), 98-103. https://doi.org/10.13037/ras.vol14n49.3671

Curado, M. A. S., Teles, J., \& Marôco, J. (2014). Análise de variáveis não diretamente observáveis: influência na tomada de decisão durante o processo de investigação. Revista da Escola de Enfermagem da USP, 48, 146-152. https://doi.org/10.1590/S0080-623420140000100019

De Marchi, L. (2014). Análise do Plano da Secretaria da Economia Criativa e as transformações na relação entre Estado e cultura no Brasil. Intercom: Revista Brasileira de Ciências da Comunicação, 37, 193-215. https://doi.org/10.1590/S1809-58442014000100010

Dodsworth, J. P. (2016). Economia Circular. [Monografia de Final de Curso - Pontifícia Universidade Católica do Rio de Janeiro]. $\quad$ Received June $20 . \quad 2021, \quad$ from http://www.econ.puc-rio.br/uploads/adm/trabalhos/files/Jorge_Pumar_Dodsworth.pdf

Duisenberg, E. D. S. (2008). Economia Criativa: uma opção de desenvolvimento viável?. In Economia Criativa como estratégia de desenvolvimento: uma visão dos países em desenvolvimento / organizado por Ana Carla Fonseca Reis: São Paulo: Itaú Cultural: Garimpo de Soluções, p. 267.

Gonçalves, A. T. P. (2016). Análise de conteúdo, análise do discurso e análise de conversação: estudo preliminar sobre diferenças conceituais e teórico-metodológicas. Administração: Ensino e Pesquisa, 17(2), 275-300. Retrieved from https://www.redalyc.org/articulo.oa?id=533560872003

Göttems, L. B. D., de Carvalho, E. M. P., Carvalho, P. A., \& Santana, L. A. (2018). Adesão às boas práticas de atenção ao parto e nascimento e análise da confiabilidade de um instrumento pelo alfa de Cronbach. Revista de Pesquisa Cuidado é Fundamental Online, 10, 272-275. https://doi.org/10.9789/2175-5361.2018.v10iEspecial.272-275

Hora, H. R. M., Monteiro, G. T. R., \& Arica, J. (2010). Confiabilidade em questionários para qualidade: um estudo com o Coeficiente Alfa de Cronbach. Produto \& Produção, 11(2). https://doi.org/10.22456/1983-8026.9321

Instituto de Pesquisa Econômica Aplicada [IPEA]. (2009). Brasil em Desenvolvimento. Estado, planejamento e políticas públicas, 3(29), 779-795. Brasília: IPEA. Received June 19, 2021, from https://www.ipea.gov.br/bd/pdf/2009/Livro_BrasilDesenvEN_Vol03.pdf

Lelis, H. R., \& Brasil, D. R. (2018). Economia criativa: Uma Análise dos Marcos Conceituais Para o Direito. Revista UNIJUIR, (49). https://doi.org/10.21527/2176-6622.2018.49.45-67

Lima, G. Â. B. D. O. (2010). Modelos de categorização: apresentando o modelo clássico e o modelo de protótipos. Perspectivas em Ciência da Informação, 15, 108-122. https://doi.org/10.1590/S1413-99362010000200008

Madeira, M. G. (2014). Economia criativa: implicações e desafios para a política externa brasileira. Brasília. FUNAG.

Marcondes, M. M., Lemos Sandim, T., \& Rodrigues Diniz, A. P. (2018). Transversalidade e Intersetorialidade: mapeamento do debate conceitual no cenário brasileiro. Administração Pública e Gestão Social, 10(1). https://doi.org/10.21118/apgs.v10i1.1527

Marconi, M. de A., \& Lakatos, E. M. (2017). Metodologia do trabalho científico, Editora Atlas (8th ed.). São Paulo.

Mikołajczak, S. (2003). Os tipos das construçõdes com clivagem em português. Studia Romanica Posnaniensia, 29, 187-196. https://doi.org/10.14746/strop.2003.29.015

Muzzio, H., \& Barbosa, F. C. (2018). No caminho para uma gestão criativa: a percepção dos gestores da economia criativa sobre suas experiências. Revista de Administração Unimep, 16(3), 108-131. Received May 14, 2020, from http://www.raunimep.com.br/ojs/index.php/rau/article/view/1179/770 
Oliveira, M. P. D., \& Starling, M. B. D. U. (2012). A economia criativa como política de desenvolvimento: Cultura, criatividade e inovação. STARLING, Mônica Barros de Lima; OLIVEIRA, Marta Procópio de; FILHO, Nelson Antônio Quadros (org). Economia criativa: um conceito em discussão. Belo Horizonte: Fundação João Pinheiro.

Pedigo, S. (2015). Será a economia, e não os projetos sociais, que conseguirá eliminar a pobreza. [Entrevista concedida a] Mariana Barros. VEJA, São Paulo. Received June 25, 2021, from https://veja.abril.com.br/brasil/sera-a-economia-e-nao-os-projetos-sociais-que-conseguira-eliminar-a-pobreza/

Pedro Filho, F. D. S., Lima, V. A., Neto, J. M. D. S., Muller, C. A. D. S., \& Costa, G. B. D. (2017). Building the capacity for sustainable innovation in the Amazon region. International Journal of Innovation and Learning, 22(1), 23-43. https://doi.org/10.1504/IJIL.2017.085246

Ribeiro, L. S. (2018). Inovação Cradle to Cradle (C2C) e circularidade: contribuições econômicas e ambientais no Brasil. Revista Iniciativa Econômica, 4(1). Received June 14, 2021, from https://periodicos.fclar.unesp.br/iniciativa/article/view/11517/7539

Santos, V. B. (2019). Belém como metrópole cultural e criativa da Amazônia: contribuições para a elaboração do plano municipal de cultura de Belém. Cadernos CEPEC, 5(7-12). Received June 15, 2021, from https://periodicos.ufpa.br/index.php/cepec/article/download/6909/5430

Sauvé, S., Bernard, S., \& Sloan, P. (2016). Environmental sciences, sustainable development and circular economy: Alternative concepts for trans-disciplinary research. Environmental Development, 17, 48-56. https://doi.org/10.1016/j.envdev.2015.09.002

Scharmer, C. O. (2010). Teoria U - Como liderar pela percepção e realização do futuro que emerge, através da mente aberta, coração aberto e vontade aberta. Editora Campus. Rio de Janeiro.

Schiavini, J. M., \& Garrido, I. (2018). Análise de Conteúdo, Discurso ou Conversa? Similaridades e Diferenças entre os Métodos de Análise Qualitativa. Revista ADM. MADE, 22(2), 1-12. https://doi.org/10.21714/2237-51392018v22n2p001012

Seifert Jr, R. E., \& Machado-da-Silva, C. L. (2007). Environment, resources and interpretation: influences in the internationalization strategies of the food industry in Brazil. BAR-Brazilian Administration Review, 4, 40-63. https://doi.org/10.1590/S1807-76922007000200004

Siedenberg, D. R. (2001). Uma abordagem epistêmico-sistêmica do conceito de desenvolvimento. REA-Revista de Estudos de Administração, 2(3).

Silva, F. B. (2018). Economia criativa: raízes históricas no pensamento e ação de celso furtado. [Tese de Doutorado, Universidade Federal da Bahia]. Received May 28, 2021, from https://repositorio.ufba.br/ri/bitstream/ri/27136/1/Tese\%20de\%20doutorado\%20de\%20Floriano\%20Barboza\%2 OSilva.pdf

Stahel, W. R. (2016). Circular economy. Nature News, 531, 435-438. https://doi.org/10.1038/531435a

\section{Copyrights}

Copyright for this article is retained by the author(s), with first publication rights granted to the journal.

This is an open-access article distributed under the terms and conditions of the Creative Commons Attribution license (http://creativecommons.org/licenses/by/4.0/). 